\title{
Discard-ban policies can help improve our understanding of the ecological role of food availability to seabirds
}

\author{
Enric Real ${ }^{1}$, Giacomo Tavecchia ${ }^{1}$, Meritxell Genovart ${ }^{2,3}$, Ana Sanz-Aguilar ${ }^{1}$, \\ Ana Payo-Payo ${ }^{1}$, Daniel Oro ${ }^{2,3}$ \\ ${ }^{1}$ Grupo de Ecología y Demografía Animal, IMEDEA, CSIC-UIB, Miquel Marquès 21, 07190 Esporles, Spain. \\ (ER) (Corresponding author) E-mail: ereal @imedea.uib-csic.es. ORCID-iD: https://orcid.org/0000-0002-6190-6303 \\ (GT) E-mail: g.tavecchia@uib.es. ORCID-iD: https://orcid.org/0000-0001-5435-2691 \\ (AS-A) E-mail: asanz@imedea.uib-csic.es. ORCID-iD: https://orcid.org/0000-0002-4177-9749 \\ (AP-P) E-mail: anapayopayo@gmail.com.ORCID-iD: https://orcid.org/0000-0001-5482-242X \\ ${ }^{2}$ IMEDEA, CSIC-UIB, Miquel Marquès 21, 07190 Esporles, Spain. \\ (MG) E-mail: m.genovart@ csic.es. ORCID-iD: https://orcid.org/0000-0003-2919-1288 \\ (DO) E-mail: d.oro@ csic.es. ORCID-iD: https://orcid.org/0000-0003-4782-3007 \\ ${ }^{3}$ Centre d'Estudis Avançats de Blanes, CSIC, Accés Cala Sant Francesc 14, 17300 Blanes, Spain.
}

\begin{abstract}
Summary: Discards from fisheries are the most important predictable anthropogenic food subsidies (PAFS) that are being incorporated into marine ecosystems. Changes on their availability and predictability can help us to understand the role that food availability (i.e. an important indicator of the carrying capacity) plays at different ecological levels, from individual fitness to community dynamic and ecosystem functioning. For several reasons, seabirds are an excellent model for evaluating the ecological effects arising from a lack of discards: 1) they are one of the most important discard scavengers, 2) they are easy to monitor and 3) they are apical predators are globally distributed, which makes them suitable health indicators of ecosystems. Here we review the existing information on seabird-discard interactions to identify the main knowledge gaps and propose new challenges for improving our understanding of the general role of food availability. We conclude that the new policies on the ban of fishery discards that are being progressively implemented in the European Union, Norway, Chile and New Zealand offer a suitable experimental scenario for improving our understanding of how a large decrease in the carrying capacity may alter demographic parameters such as survival, dispersal and reproduction, the resilience of populations against perturbations and the role of individual specialization in the foraging process.
\end{abstract}

Keywords: food availability; fishery discards; seabirds; ecological interactions; discard policies. Las políticas sobre prohibición de descartes pueden ayudar a mejorar la comprensión sobre el papel ecológico de la
disponibilidad de alimento en aves marinas

Resumen: Los descartes pesqueros constituyen el recurso antropogénico predecible (PAFS) más importante que está siendo incorporado en los ecosistemas marinos. Cambios en su disponibilidad y predictibilidad pueden ayudar a entender mejor el papel ecológico de la disponibilidad de alimento (i.e. un importante indicador de la capacidad de carga) a diferentes niveles, desde la eficacia biológica individual hasta la dinámica de poblaciones o el funcionamiento de los ecosistemas. Las aves marinas constituyen un modelo excelente para estudiar los efectos ecológicos derivados de la falta de descartes por diversas razones: las aves marinas: 1) se encuentran entre los principales carroñeros de descartes, 2) son fáciles de monitorear y 3) son depredadores apicales globalmente distribuidos, lo cual las convierte en buenas indicadoras de la salud del ecosistema. En el presente estudio revisamos la información existente sobre las interacciones ecológicas entre las aves marinas y los descartes de la pesca, con el fin de identificar los principales vacíos de conocimiento y plantear retos futuros de cara a mejorar nuestra comprensión sobre el papel ecológico que tiene la disponibilidad de alimento. Concluimos que las políticas actuales en materia de prohibición de descartes que están siendo implementadas en la Unión Europea, Noruega, Chile o Nueva Zelanda, ofrecen un escenario ideal para mejorar nuestra comprensión sobre cómo una reducción de la capacidad de carga puede alterar parámetros demográficos tales como la supervivencia, la dispersión y la reproducción, la resiliencia de las poblaciones frente a perturbaciones y el papel de la especialización individual en el proceso de forrajeo.

Palabras clave: disponibilidad de alimento; descartes pesqueros; aves marinas; interacciones ecológicas; políticas de descartes.

Citation/Cómo citar este artículo: Real E., Tavecchia G., Genovart M., Sanz-Aguilar A., Payo-Payo A., Oro D. 2018. Discard-ban policies can help improve our understanding of the ecological role of food availability to seabirds. Sci. Mar. 82S1: 115-120. https://doi.org/10.3989/scimar.04746.10A

Editor: F. Maynou. 
Received: December 22, 2017. Accepted: June 21, 2018. Published: July 25, 2018.

Copyright: ( $\odot 2018$ CSIC. This is an open-access article distributed under the terms of the Creative Commons Attribution 4.0 International (CC BY 4.0) License.

\section{INTRODUCTION}

The large amount of discards in the form of offal that are generated daily by industrial and artisanal fisheries and thrown into the sea constitutes one of the most important and predictable anthropogenic food subsidies (PAFS) that are being incorporated into marine ecosystems worldwide (Oro et al. 2013). Global discards generation in recent years has been estimated to be $c a .10$ million t/year, with a peak of 19 million $\mathrm{t} /$ year in the late 1950s (Zeller et al. 2017). As a result of the high abundance and predictability of this anthropogenic food resource, together with a decrease in the natural prey availability due to industrial fisheries, fishery discards have important ecological implications at a global level for marine scavengers, including seabirds (Votier et al. 2004, Cury et al. 2011, Bicknell et al. 2013, Oro et al. 2013). Garthe et al. (1996), for instance, estimated that 5.9 million seabirds were potentially supported by fishery discards in the North Sea.

Changes in the availability and predictability of fishery discards as PAFS can help to understand the ecological role that food availability (i.e. carrying capacity) have at multiple ecological levels, including individual fitness, community dynamics and ecosystem functioning.

Seabirds constitute an excellent model for evaluating the ecological effects arising from a lack of PAFS for several reasons: seabirds are 1) one of the most important discard scavengers at a global level, 2) easy to monitor (because they breed on land) and 3) apical predators with a global distribution, which makes them suitable bioindicators of ecosystem health. The link between seabirds and fishery discards has been reviewed in several studies (Tasker et al. 2000, Arcos et al. 2008, Wagner and Boersma 2011). However, the ecological and evolutionary implications that fishery discards have as PAFS at a global level (Oro et al. 2013), as well as the current changes in fishery policies (see e.g. Borges et al. 2016), call for a new revision of the existing information and the identification of knowledge gaps.

Here we review current knowledge on the global ecological interactions between seabirds and fishery discards in order to identify the main knowledge gaps and propose new challenges for improving our understanding of the ecological role that food availability has for populations, communities and ecosystems.

\section{METHODS}

We considered the information available in SCI journals (6 June 2017) on the Web of Science platform (WOS; Clarivate Analytics). We first selected articles with concomitant terms: [(Seabirds AND "Fishery Waste") OR (Seabirds AND Discard)] in title, abstract or keywords (Search field = Topic) as a representative sample of research focusing on the effects of discards on sea- birds' ecology. A second search with concomitant terms: [(Seabirds AND Ecosystem AND Discard) OR (Seabirds AND Ecosystem AND "Fishery Waste")] (Search field $=$ Topic) was conducted to find studies focusing on the effects arising from seabird-discard interactions at the ecosystem level. Then, the selected studies were classified according to: 1) the species and families of seabirds interacting with fishery discards, 2) the fishing gear used and 3) the ecological parameter or effect investigated. Additionally, in order to identify the areas where ecological interactions between seabirds and fishery discards are more likely to occur (e.g. with high discard availability or high presence of scavenger seabirds) we calculated: 1) the average amount of discards (in metric tons) for each major FAO fishing area (www.fao.org) from 2004 to 2014 (raw data from www.seaaroundus.org) and 2) the main distribution areas of seabird species (identified as discard scavengers by reviewed studies)(data from www. iucn.org). We considered that the level of confluence of these species within each major FAO fishing area may vary throughout the year due to the large-scale movements of migratory species.

\section{RESULTS}

A total of 166 studies addressing up to 15 different ecological effects arising from seabird-discard interactions were selected and subsequently reviewed (Table 1, Supplementary Material Table S1). A total of 111 seabird species (Table S1) belonging to 14 taxonomic families (Table 1) were identified as scavengers of fishery discards. Demersal trawlers were by far the main fishing gear involving seabird-discard interactions (98\% of studies). According to their attendance at fishing vessels, the most common discard scavengers were Laridae, Procellaridae and Diomedeidae (Table 1). The major FAO fishing areas with the highest discard availability per scavenger seabird species were the Northwest Pacific, the Eastern Central Atlantic and the Mediterranean and Black seas (Fig. 1).

Few studies quantified the effect of discards on seabirds' ecology, and most (68\%) focused on the amount/type of fishing discard in seabirds' diet and on species attendance rate. In particular, we found that for the most important scavenger seabirds (Table 1) there was a lack of studies addressing potentially important ecological effects of discards in terms of food availability on: a) demographic parameters such as survival, dispersal and reproduction, b) resilience of populations against perturbations and c) individual foraging specialization (e.g. changes of predatory interactions, foraging and migratory patterns and the possible consequences of this heterogeneity for population dynamics). More specifically, the effect of discards on scavenging seabirds' survival has only been studied in the family Laridae, and only $1 \%$ of species belonging to this family have been considered (Table 1). The effect 
Table 1. - Percentage of species (regarding the total number of species of each taxonomic family) for which different ecological effects arising from seabird-discard interactions were evaluated by reviewed studies (e.g the effect of fishery discards on the diet was evaluated in $25 \%$ of species belonging to the taxonomic family Laridae). The total number of species belonging to each family was consulted in https://www.itis. gov. The most common seabird families attending fishing vessels are shown in the upper part and less common ones in the lower part.

\begin{tabular}{|c|c|c|c|c|c|c|c|c|c|c|c|c|c|c|c|c|}
\hline Family & $\stackrel{\oplus}{\oplus}$ & 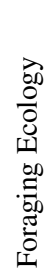 & 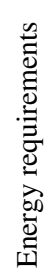 & 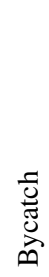 & 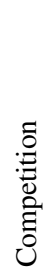 & 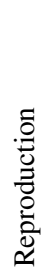 & 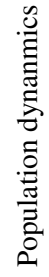 & 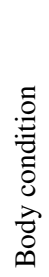 & $\begin{array}{l}\stackrel{0}{\Xi} \\
\stackrel{\Xi}{\Xi} \\
0\end{array}$ & 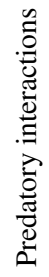 & 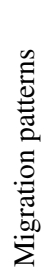 & 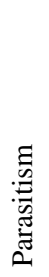 & 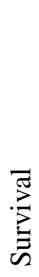 & 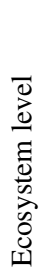 & 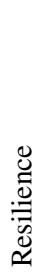 & 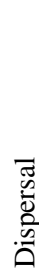 \\
\hline Laridae (102 spp.) & 25 & 12 & 13 & 11 & 15 & 4 & 9 & 3 & 6 & 3 & 0 & 4 & 1 & 0 & 2 & 1 \\
\hline Procellaridae (88 spp.) & 11 & 6 & 3 & 14 & 1 & 1 & 0 & 0 & 2 & 1 & 0 & 0 & 0 & 1 & 0 & 0 \\
\hline Diomedeidae (21 spp.) & 19 & 19 & 5 & 38 & 5 & 5 & 0 & 0 & 0 & 0 & 0 & 0 & 0 & 0 & 0 & 0 \\
\hline Sulidae (10 spp.) & 50 & 20 & 20 & 20 & 20 & 10 & 20 & 20 & 0 & 0 & 0 & 0 & 0 & 0 & 0 & 0 \\
\hline Stercorariidae (7 spp.) & 29 & 29 & 14 & 14 & 14 & 14 & 0 & 14 & 14 & 14 & 14 & 0 & 0 & 0 & 0 & 0 \\
\hline Phalacrocoracidae (37 spp.) & 5 & 0 & 3 & 3 & 3 & 0 & 0 & 0 & 3 & 0 & 0 & 0 & 0 & 0 & 0 & 0 \\
\hline Hydrobatidae (25 spp.) & 8 & 4 & 4 & 12 & 0 & 0 & 0 & 0 & 0 & 0 & 0 & 0 & 0 & 0 & 0 & 0 \\
\hline Fregatidae (5 spp.) & 40 & 0 & 0 & 0 & 20 & 0 & 0 & 0 & 0 & 0 & 0 & 0 & 0 & 0 & 0 & 0 \\
\hline Alcidae (24 spp.) & 17 & 0 & 17 & 0 & 0 & 0 & 0 & 0 & 0 & 8 & 0 & 0 & 0 & 0 & 0 & 0 \\
\hline Spheniscidae (19 spp.) & 0 & 0 & 0 & 5 & 0 & 0 & 0 & 0 & 0 & 0 & 0 & 0 & 0 & 0 & 0 & 0 \\
\hline Chionidae (2 spp.) & 0 & 0 & 0 & 50 & 0 & 0 & 0 & 0 & 0 & 0 & 0 & 0 & 0 & 0 & 0 & 0 \\
\hline Ardeidae (68 spp.) & 0 & 0 & 0 & 0 & 3 & 0 & 0 & 0 & 0 & 0 & 0 & 0 & 0 & 0 & 0 & 0 \\
\hline Cathartidae ( 7 spp.) & 0 & 0 & 0 & 0 & 29 & 0 & 0 & 0 & 0 & 0 & 0 & 0 & 0 & 0 & 0 & 0 \\
\hline Pelecanidae (8 spp.) & 13 & 0 & 0 & 0 & 0 & 0 & 0 & 0 & 0 & 0 & 0 & 0 & 0 & 0 & 0 & 0 \\
\hline
\end{tabular}

that fishery discards have on seabirds' breeding success has been hardly studied in the species belonging to the families Procellariidae (only $1 \%$ of species studied) and Diomedeidae (only $5 \%$ of species studied), which are two of the most important seabird families in terms of discard scavenger species (Table 1). We only found three studies in which individual differences in seabird foraging strategies were related to fishing practices (Matich et al. 2011, Wakefield et al. 2015, Votier et al. 2017). Finally, the role that fishery discards play in the resilience of populations remains unknown for $98 \%$ of seabirds identified as discards scavengers and for $99 \%$ of seabirds in general (Table 1).

\section{DISCUSSION}

\section{Main knowledge gaps in seabird-discard interac- tions}

\section{The effect of discards on demographic parameters and population resilience}

Fishery discards may have important ecological effects on demographic parameters and on the resilience of scavenger populations. However, these effects have never been evaluated for most of species scavenging on fishery discards. A few studies have shown that

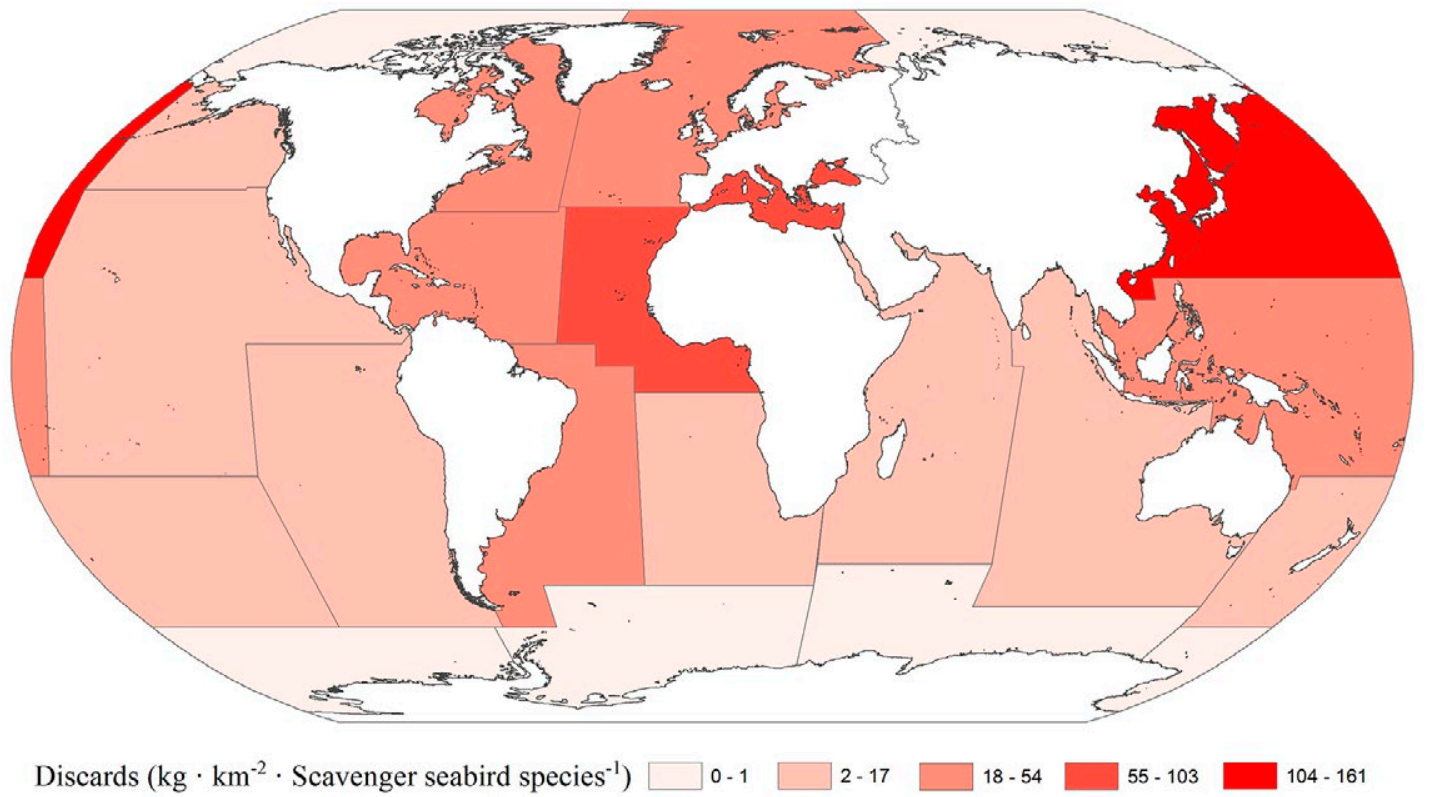

Fig. 1. - Global distribution of fishery discards availability for seabirds in different major FAO fishing areas considering amounts of discards available per unit area and number of scavenger seabird species converging in each area. 
fishery discards, like other PAFS, can increase average individual survival and reproductive output in several scavenger species (Oro et al. 2013 and references therein), but they can also reduce adult survival by increasing bycatch of scavenger seabirds. Bycatch mortality might change over time according to the composition of the fishing fleet. Laneri et al. (2010) and Soriano-Redondo et al. (2016) observed a substantial increase in seabird bycatch by longliners in the absence of discards, when trawling vessels were not operating. This suggests that a ban of fishery discards, which are mainly generated by trawling vessels, may increase the attendance of seabirds at longliners, increasing their likelihood of mortality (Laneri et al. 2010, Bicknell et al. 2013).

The availability of fishery discards could have important effects on dispersal of several species among breeding colonies, with potential consequences for the structure of communities and ecosystems. However, these effects remain unstudied for most species directly and indirectly associated with fishery discards. Oro et al. (2004), for example, showed that fishery discards such as PAFS can have a direct effect on the dispersal between breeding patches and the functioning of a spatially structured population in a long-lived seabird. Dispersal could also be indirectly affected by fishery discards through an increase on predatory interactions among sympatric species competing for food and breeding habitats when discards are not available (see González-Solís 2003). In addition, discards from fisheries and other PAFS (Real et al. 2017) could also be altering migration patterns of generalist species (Gilbert et al. 2016). Furness et al. (2006), for example, suggested that fishery discards may be affecting migration patterns of the great skua (Catharacta skua).

Fishery discards may improve average breeding success in scavenger seabirds such as Larids (Oro et al. 1995, Oro 1996a, Oro et al. 1996, 1999), shearwaters (Louzao et al. 2006, Genovart et al. 2016) and albatrosses (Rolland et al. 2008). By contrast, Pichegru et al. (2007) and Grémillet et al. (2008) observed that during periods of natural prey shortage and high energy requirements, fishery discards did not compensate for the breeding needs in Cape gannets (Morus capensis). However, more studies are needed in order to obtain a global assessment of the role that fishery discards play on the reproductive output of scavenger seabirds and to predict the consequences of discard prohibitions.

Food availability is known to increase population resilience after perturbations (see e.g. Scheffers et al. 2017). Similarly, fishery discards have been shown to buffer natural food shortages, reducing the long-term variability of population fluctuations, especially in generalist species (Oro et al. 2013, Fondo et al. 2015). However, very little is known on the role that fishery discards play in the resilience of populations in most scavenger species. Nevertheless, it is plausible to expect larger fluctuations of seabird populations after discard reduction in those ecosystems that are more tightly linked to climate anomalies and extreme climate events (Hansen et al. 2012, National Academies of Sciences 2016).

\section{Individual foraging specialization: a recent topic}

Individual specialization in foraging strategies may have important ecological implications by altering the dynamics of populations and the structure of communities and ecosystems (Bolnick et al. 2003), especially in highly mobile marine top predators (Matich et al. 2011). Within scavenger seabird populations, only certain individuals are fisherydiscard scavengers, but little is known about which individual features (e.g. age, sex, condition, behaviour traits) may influence this difference. It is likely that there is a large individual heterogeneity within populations in discard use, and this may influence variance in demographic parameters and population dynamics. Navarro et al. (2010) showed that inexperienced, younger adults of Audouin's gulls (Ichthyaetus audouinii) consumed more discards and fewer small pelagics, the natural prey of the species. Differences in resource availability (e.g. due to a ban of discards) and intraspecific competition may increase individual specialization (Matich et al. 2011). For example, when food resources (including discards) become scarce, predatory (González-Solís 2003, Regehr and Montevecchi 1997, Votier et al. 2004) and kleptoparasite (Oro 1996b) interactions among individuals may increase. Specialization in certain foraging strategies such as bird predation may have important associated advantages for individuals (e.g. by improving individual survival or breeding success). This may in turn favour the learning of these strategies by other individuals sharing the same habitat (see e.g. Annett and Pierotti 1999), with potential consequences for the structure of communities. However, despite the potential ecological consequences that individual specialization may have for populations, communities and ecosystems, little information is as yet available (but see Tuck et al. 2015).

\section{Ecosystem level effects arising from scavenger- discard interactions}

A reduction in fishery discards is expected to cause a population decrease of marine scavenger organisms (including generalist seabirds), but they can also trigger cascading effects through a change in nutrients in the water column. The general lack of studies addressing the potential impacts of fishery discards at an ecosystem level makes it difficult to predict the real ecological consequences of a ban of discards. For example, a population decrease of scavenger seabirds would alter the soil composition and the structure of animal and plant communities in coastal regions (Vidal et al. 2000, Oro et al. 2013, Ellis 2005). Hawke (2006) found a decrease in the median soil N:P molar ratio at a Westland petrel (Procellaria westlandica) breeding colony when the birds fed on fishery discards, and Calvino-Cancela (2011) showed that Larids, a group characterized by a large use of fishery discards, may act as important seed dispersers in many regions worldwide. 


\section{A chance for an experimental scenario for ecologists}

Several large areas of the world where interactions between discards from fisheries and marine scavengers could be potentially important have received little or no attention. Furthermore, most important ecological effects that fishery discards have on marine ecosystems have never or seldom been studied. Considering this, the new policies on the ban of fishery discards, which are being progressively implemented in the European Union, Norway, Chile and New Zealand, offer a suitable experimental scenario for improving our understanding of how food availability (e.g. carrying capacity) can alter the dynamics of populations and the structure of communities and ecosystems. The example given at the Ebro Delta (e.g. Oro et al. 2013), where a long-term trawling moratorium was established in the early 1990s during the breeding season of the seabird community breeding there, is illustrative of the potential that discard banning offers to ecologists in their understanding of how food availability influences ecological processes and patterns. For instance, we expect an increase in competition at intra- and interspecific level, with larger impacts on population densities for more opportunistic species, a decrease in the variance of breeding performance within populations and a decrease in the resilience of populations against anthropogenic impacts.

\section{ACKNOWLEDGEMENTS}

Funds for this study were supplied by the Spanish Ministry of Economy and by the European Social Fund (grant ref.: CGL2013-42203-R). The study also received funding from the European Commission's Horizon 2020 Research and Innovation Programme under Grant Agreement no. 634495 for the project Science, Technology, and Society Initiative to Minimize Unwanted Catches in European Fisheries (MINOUW). MG and ASA are supported by postdoctoral contracts co-funded by the Regional Government of the Balearic Islands and the European Social Fund. Two reviewers helped to improve the manuscript.

\section{REFERENCES}

Annett C.A., Pierotti R. 1999. Long-Term Reproductive Output in Western Gulls: Consequences of Alternate Tactics in Diet Choice. Ecology 80: 288-297.

https://doi.org/10.1890/0012-9658(1999)080[0288:LTROIW] 2.0.CO:2

Arcos J., Louzao M., Oro D. 2008. Fisheries ecosystem impacts and management in the Mediterranean: seabirds point of view. In: Nielsen J., Dodson J.J., Friedland K., et al. (eds) Reconciling Fisheries with Conservation. Washington DC. Am. Fish. Soc. Symp. 49: 1471-1479.

Bicknell A.W.J., Oro D., Camphuysen K. et al. 2013. Potential consequences of discard reform for seabird communities. J. Appl. Ecol. 50: 649-658. https://doi.org/10.1111/1365-2664.12072

Bolnick D.I., Svanbäck R., Fordyce J.A., et al. 2003. The ecology of individuals: incidence and implications of individual specialization. Am. Nat. 161: 1-28

https://doi.org/10.1086/343878

Borges L., Cocas L., Nielsen K.N. 2016. Discard ban and balanced harvest: a contradiction? ICES J. Mar. Sci. 73: 1632-1639.

https://doi.org/10.1093/icesims/fsw065

Calvino-Cancela M. 2011. Gulls (Laridae) as frugivores and seed dispersers. Plant. Ecol. 212: 1149-1157. https://doi.org/10.1007/s11258-011-9894-2

Cury P.M., Boyd I.L., Bonhommeau S., et al. 2011. Global Seabird Response to Forage Fish Depletion-One-Third for the Birds. Science 334: 1703-1706. https://doi.org/10.1126/science.1212928

Ellis J.C. 2005. Marine birds on land: a review of plant biomass, species richness, and community composition in seabird colonies. Plant Ecol. 181: 227-241. https://doi.org/10.1007/s11258-005-7147-y

Fondo E.N., Chaloupka M., Heymans J.J., et al. 2015. Banning Fisheries Discards Abruptly Has a Negative Impact on the Population Dynamics of Charismatic Marine Megafauna. PLoS ONE 10: e0144543. https://doi.org/10.1371/journal.pone.0144543

Furness R.W., Crane J.E., Bearhop S., et al. 2006. Techniques to link individual migration patterns of seabirds with diet specialization, condition and breeding performance. Ardea 94: 631-638.

Garthe S., Camphuysen K., Furness R. 1996. Amounts of discards by commercial fisheries and their significance as food for seabirds in the North Sea. Mar. Ecol. Prog. Ser. 136: 1-11. https://doi.org/10.3354/meps 136001

Genovart M., Arcos J.M., Álvarez D., et al. 2016. Demography of the critically endangered Balearic shearwater: the impact of fisheries and time to extinction. J. Appl. Ecol. 53: 1158-1168. https://doi.org/10.1111/1365-2664.12622

Gilbert N.I., Correia R.A., Silva J.P., et al. 2016. Are white storks addicted to junk food? Impacts of landfill use on the movement and behaviour of resident white storks (Ciconia ciconia) from a partially migratory population. Mov. Ecol. 4: 7. https://doi.org/10.1186/s40462-016-0070-0

González-Solís J. 2003. Impact of fisheries on activity, diet and predatory interactions between yellow-legged and Audouin's gulls breeding at the Chafarinas Islands. Sci. Mar. 67: 83-88. https://doi.org/10.3989/scimar.2003.67s283

Grémillet D., Pichegru L., Kuntz G., et al. 2008. A junk-food hypothesis for gannets feeding on fishery waste. Proc. R. Soc. B. Biol. Sci. 275: 1149-1156. https://doi.org/10.1098/rspb.2007.1763

Hansen J., Sato M., Ruedy R. 2012. Perception of climate change. Proc. Natl. Acad. Sci. 109: E2415-E2423. https://doi.org/10.1073/pnas.1205276109

Hawke D.J. 2006. Soil P in a forested seabird colony: inventories, parent material contributions, and N:P stoichiometry. Soil. Res. 43: $957-962$. https://doi.org/10.1071/SR05075

Laneri K., Louzao M., Martínez-Abraín A., et al. 2010. Trawling regime influences longline seabird bycatch in the Mediterranean: new insights from a small-scale fishery. Mar. Ecol. Prog. Ser. 420: $241-252$ https://doi.org/10.3354/meps08847

Louzao M., Igual J.M., McMinn M., et al. 2006. Small pelagic fish, trawling discards and breeding performance of the critically endangered Balearic shearwater: improving conservation diagnosis. Mar. Ecol. Prog. Ser. 318: 247-254. https://doi.org/10.3354/meps318247

Matich P., Heithaus M.R., Layman C.A. 2011. Contrasting patterns of individual specialization and trophic coupling in two marine apex predators. J. Anim. Ecol. 80: 294-305. https://doi.org/10.1111/j.1365-2656.2010.01753x

National Academies of Sciences, Engineering, and Medicine. 2016. Attribution of Extreme Weather Events in the Context of Climate Change. The National Academies Press, Washington, DC. $186 \mathrm{pp}$.

https://www.nap.edu/catalog/21852/attribution-of-extremeweather-events-in-the-context-of-climate-change

Navarro J., Oro D., Bertolero A., et al. 2010. Age and sexual differences in the exploitation of two anthropogenic food resources for an opportunistic seabird. Mar. Biol. 157: 2453-2459. https://doi.org/10.1007/s00227-010-1509-2

Oro D. 1996a. Effects of trawler discard availability on egg laying and breeding success in the lesser black-backed gull Larus fuscus in the western Mediterranean. Mar. Ecol. Prog. Ser. 132: 43-46. https://doi.org/10.3354/meps 132043

Oro D. 1996b. Interspecific kleptoparasitism in Audouin's Gull Larus audouinii at the Ebro Delta, northeast Spain: a behavioural 
response to low food availability. Ibis $138: 218-221$. https://doi.org/10.1111/j.1474-919X.1996.tb04331.x

Oro D., Bosch M., Ruiz X. 1995. Effects of a trawling moratorium on the breeding success of the Yellow-legged Gull Larus cachinnans. Ibis 137: 547-549.

https://doi.org/10.1111/j.1474-919X.1995.tb03265.x

Oro D., Jover L., Ruiz X. 1996. Influence of trawling activity on the breeding ecology of a threatened seabird, Audouin's gull Larus audouinii. Mar. Ecol. Prog. Ser. 139: 19-29. https://doi.org/10.3354/meps 139019

Oro D., Pradel R., Lebreton J-D. 1999. Food availability and nest predation influence life history traits in Audouin's gull, Larus audouinii. Oecologia 118: 438-445. https://doi.org/10.1007/s004420050746

Oro D., Cam E., Pradel R., et al. 2004. Influence of food availability on demography and local population dynamics in a long-lived seabird. Proc. R. Soc. Lond. B. Biol. Sci. 271: 387-396. https://doi.org/10.1098/rspb.2003.2609

Oro D., Genovart M., Tavecchia G., et al. 2013. Ecological and evolutionary implications of food subsidies from humans. Ecol. Lett. 16: 1501-1514. https://doi.org/10.1111/ele.12187

Pichegru L., Ryan P.G., van der Lingen C.D., et al. 2007. Foraging behaviour and energetics of Cape gannets Morus capensis feeding on live prey and fishery discards in the Benguela upwelling system. Mar. Ecol. Prog. Ser. 350: 127-136. https://doi.org/10.3354/meps07128

Real E., Oro D., Martínez-Abraín A., et al. 2017. Predictable anthropogenic food subsidies, density-dependence and socioeconomic factors influence breeding investment in a generalist seabird. J. Avian Biol. 48: 1462-1470. https://doi.org/10.1111/jav.01454

Regehr H.M., Montevecchi W.A. 1997. Interactive effects of food shortage and predation on breeding failure of black-legged kittiwakes: indirect effects of fisheries activities and implications for indicator species. Mar. Ecol. Prog. Ser. 155: 249-260. https://doi.org/10.3354/meps 155249

Rolland V., Barbraud C., Weimerskirch H. 2008. Combined Effects of Fisheries and Climate on a Migratory Long-Lived Marine Predator. J. Appl. Ecol. 45: 4-13. https://doi.org/10.1111/j.1365-2664.2007.01360.x

Scheffers B.R., Shoo L., Phillips B., et al. 2017. Vertical (arboreality) and horizontal (dispersal) movement increase the resilience of vertebrates to climatic instability. Glob. Ecol. Biogeogr. 26: 787-798. https://doi.org/10.1111/geb.12585

Soriano-Redondo A., Cortés V., Reyes-González J.M., et al. 2016. Relative abundance and distribution of fisheries influence risk of seabird bycatch. Sci. Rep. 6: 37373 . https://doi.org/10.1038/srep37373

Tasker M.L., Camphuysen C.J., Cooper J., et al. 2000. The impacts of fishing on marine birds. ICES J. Mar. Sci. 57: 531-547. https://doi.org/10.1006/jmsc.2000.0714

Tuck G.N., Thomson R.B., Barbraud C., et al. 2015. An integrated assessment model of seabird population dynamics: can individual heterogeneity in susceptibility to fishing explain abundance trends in Crozet wandering albatross? J. Appl. Ecol. 52: 950-959. https://doi.org/10.1111/1365-2664.12462

Vidal E., Médail F., Tatoni T., et al. 2000. Seabirds drive plant species turnover on small Mediterranean islands at the expense of native taxa. Oecologia 122: 427-434. https://doi.org/10.1007/s004420050049

Votier S.C., Furness R.W., Bearhop S., et al. 2004. Changes in fisheries discard rates and seabird communities. Nature 427: 727-730. https://doi.org/10.1038/nature02315

Votier S.C., Fayet A.L., Bearhop S., et al. 2017. Effects of age and reproductive status on individual foraging site fidelity in a long-lived marine predator. Proc. R. Soc. B. Biol. Sci. 284: 20171068. https://doi.org/10.1098/rspb.2017.1068

Wagner E.L., Boersma P.D. 2011. Effects of Fisheries on Seabird Community Ecology. Rev. Fish. Sci. 19: 157-167. https://doi.org/10.1080/10641262.2011.562568

Wakefield E.D., Cleasby I.R., Bearhop S., et al. 2015. Long-term individual foraging site fidelity - why some gannets don't change their spots. Ecology 96: 3058-3074. https://doi.org/10.1890/14-1300.1

Zeller D., Cashion T., Palomares M., et al. 2017. Global marine fisheries discards: A synthesis of reconstructed data. Fish Fish. 19: 30-39.

https://doi.org/10.1111/faf.12233

\section{SUPPLEMENTARY MATERIAL}

The following supplementary material is available through the online version of this article and at the following link:

http://scimar.icm.csic.es/scimar/supplm/sm04746esm.pdf

Table S1. - Seabird species identified as scavengers of fishery discards according to reviewed studies and number of studies considering each ecological effect derived from seabird-discard interactions. 


\section{Discard-ban policies can help improve our understanding of the ecological role of food availability to seabirds}

Enric Real, Giacomo Tavecchia, Meritxell Genovart, Ana Sanz-Aguilar, Ana Payo-Payo, Daniel Oro

Supplementary material 
Table S1. - Seabird species identified as scavengers of fishery discards according to reviewed studies and number of studies considering each ecological effect derived from seabird-discard interactions.

\begin{tabular}{|c|c|c|c|c|c|c|c|c|c|c|c|c|c|c|c|c|}
\hline Species & $\stackrel{\stackrel{ \pm}{0}}{a}$ & $\begin{array}{l}\overrightarrow{00} \\
\frac{0}{0} \\
0 \\
\text { II } \\
00 \\
.0 \\
.00 \\
0 \\
0 \\
0\end{array}$ & 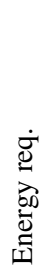 & 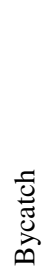 & 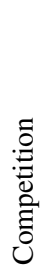 & 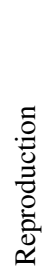 & 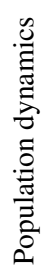 & 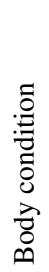 & 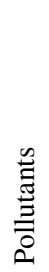 & 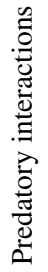 & 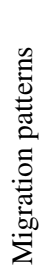 & 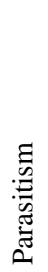 & $\sum_{\tilde{D}}^{\pi}$ & 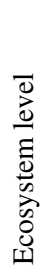 & 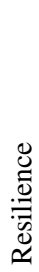 & 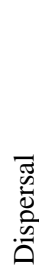 \\
\hline Alca torda & 1 & 0 & 1 & 0 & 0 & 0 & 0 & 0 & 0 & 0 & 0 & 0 & 0 & 0 & 0 & 0 \\
\hline Alle alle & 0 & 1 & 0 & 0 & 0 & 0 & 0 & 0 & 0 & 0 & 0 & 0 & 0 & 0 & 0 & 0 \\
\hline Anous minutus & 0 & 0 & 0 & 0 & 0 & 0 & 1 & 0 & 0 & 0 & 0 & 0 & 0 & 0 & 0 & 0 \\
\hline Anous stoldius & 1 & 0 & 0 & 0 & 0 & 0 & 1 & 0 & 0 & 0 & 0 & 0 & 0 & 0 & 0 & 0 \\
\hline Ardea alba & 0 & 1 & 0 & 0 & 1 & 0 & 0 & 0 & 0 & 0 & 0 & 0 & 0 & 0 & 0 & 0 \\
\hline Ardenna gravis & 1 & 5 & 0 & 4 & 0 & 0 & 0 & 0 & 0 & 0 & 0 & 0 & 0 & 0 & 0 & 0 \\
\hline Ardenna grisea & 2 & 4 & 0 & 3 & 0 & 0 & 0 & 0 & 0 & 0 & 0 & 0 & 0 & 0 & 0 & 0 \\
\hline Ardenna tenuirostris & 1 & 0 & 0 & 0 & 0 & 0 & 0 & 0 & 0 & 0 & 0 & 0 & 0 & 0 & 0 & 0 \\
\hline Calonectris borealis & 0 & 1 & 0 & 0 & 0 & 0 & 0 & 0 & 0 & 0 & 0 & 0 & 0 & 0 & 0 & 0 \\
\hline Calonectris diomedea & 3 & 11 & 2 & 2 & 0 & 0 & 0 & 0 & 0 & 0 & 0 & 0 & 0 & 0 & 0 & 0 \\
\hline Catharacta antarctica & 0 & 1 & 0 & 3 & 0 & 0 & 0 & 0 & 0 & 0 & 0 & 0 & 0 & 0 & 0 & 0 \\
\hline Catharacta skua & 12 & 7 & 3 & 0 & 2 & 1 & 0 & 1 & 1 & 1 & 0 & 0 & 0 & 0 & 0 & 0 \\
\hline Cathartes aura & 0 & 1 & 0 & 0 & 1 & 0 & 0 & 0 & 0 & 0 & 0 & 0 & 0 & 0 & 0 & 0 \\
\hline Chionis alba & 0 & 2 & 0 & 2 & 0 & 0 & 0 & 0 & 0 & 0 & 0 & 0 & 0 & 0 & 0 & 0 \\
\hline Chlidonias hybridus & 0 & 0 & 0 & 0 & 0 & 0 & 0 & 0 & 1 & 0 & 0 & 0 & 0 & 0 & 0 & 0 \\
\hline Chlidonias niger & 1 & 3 & 1 & 0 & 0 & 0 & 0 & 0 & 0 & 0 & 0 & 0 & 0 & 0 & 0 & 0 \\
\hline Chroicocephalus cirrocephalus & 0 & 1 & 0 & 0 & 0 & 0 & 0 & 0 & 0 & 0 & 0 & 0 & 0 & 0 & 0 & 0 \\
\hline Chroicocephalus maculipennis & 0 & 1 & 0 & 0 & 0 & 0 & 0 & 0 & 0 & 0 & 0 & 0 & 0 & 0 & 0 & 0 \\
\hline Chroicocephalus novaehollandiae & 1 & 1 & 0 & 0 & 0 & 0 & 0 & 0 & 0 & 0 & 0 & 0 & 0 & 0 & 0 & 0 \\
\hline Chroicocephalus ridibundus & 4 & 8 & 3 & 0 & 2 & 0 & 0 & 0 & 0 & 0 & 0 & 1 & 0 & 0 & 0 & 0 \\
\hline Coragyps atratus & 0 & 1 & 0 & 0 & 1 & 0 & 0 & 0 & 0 & 0 & 0 & 0 & 0 & 0 & 0 & 0 \\
\hline Daption capense & 1 & 4 & 0 & 4 & 0 & 0 & 0 & 0 & 0 & 0 & 0 & 0 & 0 & 0 & 0 & 0 \\
\hline Diomedea amsterdamensis & 0 & 1 & 0 & 1 & 0 & 0 & 0 & 0 & 0 & 0 & 0 & 0 & 0 & 0 & 0 & 0 \\
\hline Diomedea dabbenena & 1 & 0 & 0 & 0 & 0 & 0 & 0 & 0 & 0 & 0 & 0 & 0 & 0 & 0 & 0 & 0 \\
\hline Diomedea epomophora & 0 & 1 & 0 & 4 & 0 & 0 & 0 & 0 & 0 & 0 & 0 & 0 & 0 & 0 & 0 & 0 \\
\hline Diomedea exulans & 2 & 3 & 0 & 2 & 0 & 0 & 0 & 0 & 0 & 0 & 0 & 0 & 0 & 0 & 0 & 0 \\
\hline Diomedea sanfordi & 0 & 1 & 0 & 2 & 0 & 0 & 0 & 0 & 0 & 0 & 0 & 0 & 0 & 0 & 0 & 0 \\
\hline Egretta caerulea & 0 & 1 & 0 & 0 & 0 & 0 & 0 & 0 & 0 & 0 & 0 & 0 & 0 & 0 & 0 & 0 \\
\hline Egretta thula & 0 & 1 & 0 & 0 & 1 & 0 & 0 & 0 & 0 & 0 & 0 & 0 & 0 & 0 & 0 & 0 \\
\hline Fratercula arctica & 1 & 1 & 1 & 0 & 0 & 0 & 0 & 0 & 0 & 1 & 0 & 0 & 0 & 0 & 0 & 0 \\
\hline Fregata ariel & 1 & 1 & 0 & 0 & 0 & 0 & 0 & 0 & 0 & 0 & 0 & 0 & 0 & 0 & 0 & 0 \\
\hline Fregata magnificens & 0 & 4 & 0 & 0 & 1 & 0 & 0 & 0 & 0 & 0 & 0 & 0 & 0 & 0 & 0 & 0 \\
\hline Fregata minor & 1 & 0 & 0 & 0 & 0 & 0 & 0 & 0 & 0 & 0 & 0 & 0 & 0 & 0 & 0 & 0 \\
\hline Fregetta tropica & 0 & 1 & 0 & 0 & 0 & 0 & 0 & 0 & 0 & 0 & 0 & 0 & 0 & 0 & 0 & 0 \\
\hline Fulmarus glacialis & 10 & 6 & 6 & 1 & 4 & 0 & 0 & 0 & 0 & 1 & 0 & 0 & 0 & 0 & 0 & 0 \\
\hline Fulmarus glacialoides & 0 & 1 & 0 & 2 & 0 & 0 & 0 & 0 & 0 & 0 & 0 & 0 & 0 & 0 & 0 & 0 \\
\hline Gelochelidon nilotica & 0 & 0 & 0 & 0 & 1 & 0 & 0 & 0 & 1 & 0 & 0 & 0 & 0 & 0 & 0 & 0 \\
\hline Halobaena caerulea & 0 & 1 & 0 & 1 & 0 & 0 & 0 & 0 & 0 & 0 & 0 & 0 & 0 & 0 & 0 & 0 \\
\hline Hydrobates pelagicus & 2 & 6 & 2 & 1 & 0 & 0 & 0 & 0 & 0 & 0 & 0 & 0 & 0 & 0 & 0 & 0 \\
\hline Hydroprogne caspia & 1 & 0 & 0 & 0 & 0 & 0 & 0 & 0 & 0 & 0 & 0 & 0 & 0 & 0 & 0 & 0 \\
\hline Ichthyaetus audouinii & 8 & 11 & 2 & 1 & 3 & 2 & 1 & 1 & 2 & 1 & 0 & 1 & 2 & 0 & 1 & 1 \\
\hline Ichthyaetus melanocephalus & 0 & 2 & 0 & 1 & 0 & 0 & 0 & 0 & 0 & 0 & 0 & 0 & 0 & 0 & 0 & 0 \\
\hline Larus argentatus & 11 & 7 & 4 & 0 & 4 & 0 & 3 & 1 & 0 & 0 & 0 & 1 & 0 & 0 & 0 & 0 \\
\hline Larus atlanticus & 0 & 2 & 0 & 0 & 0 & 0 & 0 & 0 & 0 & 0 & 0 & 0 & 0 & 0 & 0 & 0 \\
\hline Larus canus & 3 & 5 & 2 & 0 & 1 & 0 & 0 & 0 & 0 & 0 & 0 & 0 & 0 & 0 & 0 & 0 \\
\hline Larus dominicanus & 4 & 10 & 0 & 7 & 2 & 0 & 0 & 0 & 0 & 0 & 0 & 0 & 0 & 0 & 0 & 0 \\
\hline Larus fuscus & 11 & 13 & 3 & 1 & 3 & 1 & 0 & 0 & 0 & 0 & 0 & 0 & 0 & 0 & 0 & 0 \\
\hline Larus genei & 1 & 1 & 1 & 0 & 1 & 0 & 0 & 0 & 0 & 0 & 0 & 0 & 0 & 0 & 0 & 0 \\
\hline Larus hyperboreus & 0 & 1 & 0 & 0 & 0 & 0 & 0 & 0 & 0 & 0 & 0 & 0 & 0 & 0 & 0 & 0 \\
\hline Larus marinus & 4 & 6 & 2 & 0 & 3 & 0 & 2 & 1 & 0 & 0 & 0 & 0 & 0 & 0 & 0 & 0 \\
\hline Larus michahellis & 6 & 8 & 2 & 1 & 3 & 1 & 0 & 0 & 1 & 1 & 0 & 1 & 0 & 0 & 0 & 0 \\
\hline Larus minutus & 1 & 0 & 0 & 0 & 0 & 0 & 0 & 0 & 0 & 0 & 0 & 0 & 0 & 0 & 0 & 0 \\
\hline Larus pacificus & 1 & 1 & 0 & 0 & 0 & 0 & 0 & 0 & 0 & 0 & 0 & 0 & 0 & 0 & 0 & 0 \\
\hline Larus sabini & 0 & 1 & 0 & 0 & 0 & 0 & 0 & 0 & 0 & 0 & 0 & 0 & 0 & 0 & 0 & 0 \\
\hline Leucocarbo atriceps & 0 & 2 & 0 & 4 & 0 & 0 & 0 & 0 & 0 & 0 & 0 & 0 & 0 & 0 & 0 & 0 \\
\hline Leucophaeus atricilla & 1 & 1 & 0 & 0 & 0 & 0 & 0 & 0 & 0 & 0 & 0 & 0 & 0 & 0 & 0 & 0 \\
\hline Macronectes giganteus & 1 & 5 & 0 & 6 & 0 & 0 & 0 & 0 & 0 & 0 & 0 & 0 & 0 & 0 & 0 & 0 \\
\hline Macronectes halli & 0 & 2 & 0 & 3 & 0 & 0 & 0 & 0 & 0 & 0 & 0 & 0 & 0 & 0 & 0 & 0 \\
\hline Morus bassanus & 10 & 12 & 2 & 1 & 3 & 0 & 0 & 1 & 0 & 0 & 1 & 0 & 0 & 0 & 0 & 0 \\
\hline Morus capensis & 5 & 5 & 3 & 1 & 0 & 3 & 0 & 1 & 0 & 0 & 0 & 0 & 0 & 0 & 0 & 0 \\
\hline Morus serrator & 0 & 0 & 0 & 0 & 0 & 0 & 1 & 0 & 0 & 0 & 0 & 0 & 0 & 0 & 0 & 0 \\
\hline Oceanites oceanicus & 1 & 3 & 0 & 4 & 0 & 0 & 0 & 0 & 0 & 0 & 0 & 0 & 0 & 0 & 0 & 0 \\
\hline Oceanodroma leucorhoa & 0 & 1 & 0 & 0 & 0 & 0 & 0 & 0 & 0 & 0 & 0 & 0 & 0 & 0 & 0 & 0 \\
\hline Onychoprion anaethetus & 1 & 0 & 0 & 0 & 0 & 0 & 1 & 0 & 0 & 0 & 0 & 0 & 0 & 0 & 0 & 0 \\
\hline Pachyptila belcheri & 0 & 1 & 0 & 1 & 0 & 0 & 0 & 0 & 0 & 0 & 0 & 0 & 0 & 0 & 0 & 0 \\
\hline Pagodroma nivea & 0 & 1 & 0 & 0 & 0 & 0 & 0 & 0 & 0 & 0 & 0 & 0 & 0 & 0 & 0 & 0 \\
\hline Pelecanus occidentalis & 1 & 1 & 0 & 0 & 0 & 0 & 0 & 0 & 0 & 0 & 0 & 0 & 0 & 0 & 0 & 0 \\
\hline Phalacrocorax aristotelis & 2 & 2 & 1 & 0 & 0 & 0 & 0 & 0 & 1 & 0 & 0 & 0 & 0 & 0 & 0 & 0 \\
\hline
\end{tabular}


Table S1 (Cont.). - Seabird species identified as scavengers of fishery discards according to reviewed studies and number of studies considering each ecological effect derived from seabird-discard interactions.

\begin{tabular}{|c|c|c|c|c|c|c|c|c|c|c|c|c|c|c|c|c|}
\hline Species & $\stackrel{\overrightarrow{0}}{\overrightarrow{0}}$ & 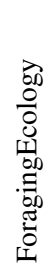 & 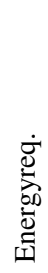 & 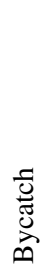 & 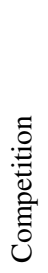 & 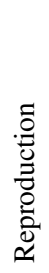 & 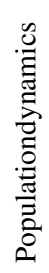 & $\begin{array}{l}\tilde{0} \\
: \\
0 \\
0 \\
0 \\
0 \\
0 \\
0 \\
0\end{array}$ & 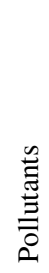 & 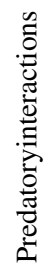 & 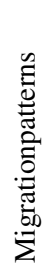 & 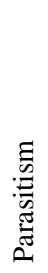 & $\underset{\infty}{\stackrel{F}{D}}$ & 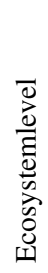 & 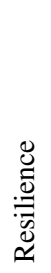 & 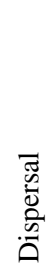 \\
\hline Phalacrocorax brasilianus & 0 & 3 & 0 & 0 & 1 & 0 & 0 & 0 & 0 & 0 & 0 & 0 & 0 & 0 & 0 & 0 \\
\hline Phalacrocorax carbo & 1 & 0 & 0 & 0 & 0 & 0 & 0 & 0 & 0 & 0 & 0 & 0 & 0 & 0 & 0 & 0 \\
\hline Phalacrocorax olivaceus & 0 & 1 & 0 & 0 & 0 & 0 & 0 & 0 & 0 & 0 & 0 & 0 & 0 & 0 & 0 & 0 \\
\hline Phoebetria fusca & 0 & 1 & 0 & 1 & 0 & 0 & 0 & 0 & 0 & 0 & 0 & 0 & 0 & 0 & 0 & 0 \\
\hline Phoebetria palpebrata & 0 & 0 & 0 & 1 & 0 & 0 & 0 & 0 & 0 & 0 & 0 & 0 & 0 & 0 & 0 & 0 \\
\hline Procellaria aequinoctialis & 0 & 7 & 0 & 6 & 0 & 0 & 0 & 0 & 1 & 0 & 0 & 0 & 0 & 0 & 0 & 0 \\
\hline Procellaria conspicillata & 1 & 3 & 0 & 1 & 0 & 0 & 0 & 0 & 1 & 0 & 0 & 0 & 0 & 0 & 0 & 0 \\
\hline Procellaria westlandica & 1 & 1 & 0 & 0 & 0 & 0 & 0 & 0 & 0 & 0 & 0 & 0 & 0 & 1 & 0 & 0 \\
\hline Pterodroma macroptera & 1 & 1 & 0 & 1 & 0 & 0 & 0 & 0 & 0 & 0 & 0 & 0 & 0 & 0 & 0 & 0 \\
\hline Pterodroma mollis & 0 & 0 & 0 & 1 & 0 & 0 & 0 & 0 & 0 & 0 & 0 & 0 & 0 & 0 & 0 & 0 \\
\hline Puffinus assimilis & 0 & 1 & 0 & 0 & 0 & 0 & 0 & 0 & 0 & 0 & 0 & 0 & 0 & 0 & 0 & 0 \\
\hline Puffinus mauretanicus & 4 & 8 & 1 & 1 & 0 & 2 & 0 & 0 & 0 & 0 & 0 & 0 & 0 & 0 & 0 & 0 \\
\hline Puffinus puffinus & 0 & 1 & 0 & 0 & 0 & 0 & 0 & 0 & 0 & 0 & 0 & 0 & 0 & 0 & 0 & 0 \\
\hline Puffinus yelkouan & 0 & 1 & 0 & 0 & 0 & 0 & 0 & 0 & 0 & 0 & 0 & 0 & 0 & 0 & 0 & 0 \\
\hline Pygoscelis antarcticus & 0 & 1 & 0 & 0 & 0 & 0 & 0 & 0 & 0 & 0 & 0 & 0 & 0 & 0 & 0 & 0 \\
\hline Pygoscelis papua & 0 & 1 & 0 & 0 & 0 & 0 & 0 & 0 & 0 & 0 & 0 & 0 & 0 & 0 & 0 & 0 \\
\hline Rissa tridactyla & 5 & 7 & 3 & 1 & 1 & 1 & 0 & 0 & 0 & 2 & 0 & 0 & 0 & 0 & 0 & 0 \\
\hline Spheniscus magellanicus & 0 & 1 & 0 & 4 & 0 & 0 & 0 & 0 & 0 & 0 & 0 & 0 & 0 & 0 & 0 & 0 \\
\hline Stercorarius parasiticus & 0 & 2 & 0 & 0 & 0 & 0 & 0 & 0 & 0 & 0 & 0 & 0 & 0 & 0 & 0 & 0 \\
\hline Stercorarius pomarinus & 1 & 4 & 0 & 0 & 0 & 0 & 0 & 0 & 0 & 0 & 0 & 0 & 0 & 0 & 0 & 0 \\
\hline Sterna dougallii & 1 & 2 & 0 & 0 & 0 & 0 & 0 & 0 & 0 & 0 & 0 & 0 & 0 & 0 & 0 & 0 \\
\hline Sterna hirundinacea & 0 & 6 & 0 & 5 & 2 & 0 & 0 & 0 & 0 & 0 & 0 & 0 & 0 & 0 & 0 & 0 \\
\hline Sterna hirundo & 3 & 9 & 3 & 1 & 0 & 0 & 0 & 0 & 2 & 0 & 0 & 0 & 0 & 0 & 0 & 0 \\
\hline Sterna paradisaea & 0 & 1 & 0 & 0 & 0 & 0 & 0 & 0 & 0 & 0 & 0 & 0 & 0 & 0 & 0 & 0 \\
\hline Sterna sumatrana & 1 & 0 & 0 & 0 & 0 & 0 & 1 & 0 & 0 & 0 & 0 & 0 & 0 & 0 & 0 & 0 \\
\hline Sterna vittata & 0 & 1 & 0 & 0 & 0 & 0 & 0 & 0 & 0 & 0 & 0 & 0 & 0 & 0 & 0 & 0 \\
\hline Sternula alfibrons & 0 & 0 & 0 & 0 & 1 & 0 & 0 & 0 & 0 & 0 & 0 & 0 & 0 & 0 & 0 & 0 \\
\hline Sula dactylatra & 1 & 0 & 0 & 0 & 0 & 0 & 0 & 0 & 0 & 0 & 0 & 0 & 0 & 0 & 0 & 0 \\
\hline Sula leucogaster & 1 & 3 & 0 & 0 & 1 & 0 & 1 & 0 & 0 & 0 & 0 & 0 & 0 & 0 & 0 & 0 \\
\hline Sula sula & 1 & 0 & 0 & 0 & 0 & 0 & 0 & 0 & 0 & 0 & 0 & 0 & 0 & 0 & 0 & 0 \\
\hline Thalassarche bulleri & 1 & 1 & 0 & 0 & 0 & 0 & 0 & 0 & 0 & 0 & 0 & 0 & 0 & 0 & 0 & 0 \\
\hline Thalassarche cauta & 0 & 2 & 0 & 2 & 0 & 0 & 0 & 0 & 0 & 0 & 0 & 0 & 0 & 0 & 0 & 0 \\
\hline Thalassarche chlororhynchos & 0 & 2 & 0 & 1 & 0 & 0 & 0 & 0 & 0 & 0 & 0 & 0 & 0 & 0 & 0 & 0 \\
\hline Thalassarche chrysostoma & 0 & 2 & 0 & 2 & 0 & 0 & 0 & 0 & 0 & 0 & 0 & 0 & 0 & 0 & 0 & 0 \\
\hline Thalassarche melanophrys & 6 & 14 & 1 & 9 & 1 & 1 & 0 & 0 & 0 & 0 & 0 & 0 & 0 & 0 & 0 & 0 \\
\hline Thalassarche steadi & 0 & 2 & 0 & 0 & 0 & 0 & 0 & 0 & 0 & 0 & 0 & 0 & 0 & 0 & 0 & 0 \\
\hline Thalasseus acuflavidus & 0 & 1 & 0 & 1 & 0 & 0 & 0 & 0 & 0 & 0 & 0 & 0 & 0 & 0 & 0 & 0 \\
\hline Thalasseus bengalensis & 1 & 0 & 0 & 0 & 0 & 0 & 1 & 0 & 0 & 0 & 0 & 0 & 0 & 0 & 0 & 0 \\
\hline Thalasseus bergii & 1 & 1 & 0 & 0 & 0 & 0 & 1 & 0 & 0 & 0 & 0 & 0 & 0 & 0 & 1 & 0 \\
\hline Thalasseus maximus & 2 & 4 & 0 & 1 & 1 & 0 & 0 & 0 & 0 & 0 & 0 & 0 & 0 & 0 & 0 & 0 \\
\hline Thalasseus sandvicensis & 4 & 10 & 2 & 2 & 2 & 0 & 0 & 0 & 1 & 0 & 0 & 0 & 0 & 0 & 0 & 0 \\
\hline Uria aalge & 4 & 1 & 2 & 0 & 0 & 0 & 0 & 0 & 0 & 1 & 0 & 0 & 0 & 0 & 0 & 0 \\
\hline Uria lombia & 1 & 0 & 1 & 0 & 0 & 0 & 0 & 0 & 0 & 0 & 0 & 0 & 0 & 0 & 0 & 0 \\
\hline
\end{tabular}

